\title{
Tissue Nutrient Content in Ulva spp. (Chlorophyceae) as Bioindicator for Nutrient Loading Along the Coast of East Africa
}

\author{
Gustaf Lilliesköld Sjöö* and Erik Mörk
}

Department of Systems Ecology, Stockholm University, S-106 91 Stockholm, Sweden

\begin{abstract}
Eutrophication is an increasingly occurring problem that causes degradation of coastal ecosystems worldwide. Traditional monitoring of dissolved nutrients in the water column can be complicated by short term fluctuations, especially when levels of nutrients are low and turnover rapid. A proposed alternative method is the use of macroalgal tissue nutrient concentrations for indication of ambient nutrient availability, as they integrate nutrients over time. This study evaluates the use of macroalgae within the genus Ulva (Chlorophyceae), regarding their ability to reflect nutrient gradients off the coast of East Africa (i.e. Kenya and Tanzania). Ulva was able to reflect nitrogen (N) gradients from all three outlet sources, with up to $90 \%$ higher tissue $\mathrm{N}$ levels in vicinity of major cities compared to adjacent areas. Together with results from nutrient- uptake and fluctuation experiments, this study suggests that macroalgal tissue nutrient content has potential as a complement to regular water nutrient sampling.
\end{abstract}

Keywords: Macroalgae, Eutrophication, Ulva, Nutrients, Monitoring, East Africa.

\section{INTRODUCTION}

Eutrophication is an increasing phenomenon in many coastal waters, usually resulting from continuous nutrient loading of the system [1]. Effects of eutrophication often result in gradual shifts between successional states (e.g. [24]), ranging from clear water conditions dominated by benthic communities, to states of high water turbidity, dominated by phytoplankton [3]. However, in some systems eutrophication does not result in a gradual change of ecosystem structure and functions, but may instead contribute to ecosystem "phase shifts", resulting in altered dominance regimes and potential loss of biodiversity [1,5-7], Rapid phase shifts, as a result of increased nutrient levels, seem to be more common in ecosystems that normally are subjected to low background loads of nutrients, such as tropical coastal waters, and especially coral reefs [8]. It is therefore important to detect and monitor the flow of nutrients in tropical coastal areas, in order to predict and prevent harmful effects of eutrophication.

Water column nutrients are commonly used for estimation of loading and establishment of nutrient thresholds for macroalgal productivity $[8,9]$. However, studies have shown that coastal marine ecosystems often display little correlation between dissolved nutrient concentrations and the productivity of primary producers, as productivity also depend on e.g. physical and biogeochemical fluxes [10], physiological [11] morphological attributes of the producers [12], water turbulence and other environmental factors (e.g. [1, 12, 13]). Since macroalgae are capable of taking up organic forms

*Address correspondence to this author at the Department of Systems Ecology, Stockholm University, S-106 91 Stockholm, Sweden; Tel.: +46-8-16 17 44; Fax: + 46-8-158417; E-mail: gustafls@ecology.su.se of both nitrogen $(\mathrm{N})$ (e.g. urea and amino acids) [14] and phosphorous (e.g. organophosphates) [15], it may even be misleading to use water column concentrations of inorganic nutrients (e.g. $\mathrm{NO}_{2}, \mathrm{NO}_{3}, \mathrm{NH}_{4}$ and $\mathrm{PO}_{4}$ ) for estimations of bioavailable nutrients in a water body [16, 17]. Furthermore, nutrients in the water column do seldom represent the actual nutrient loading, as losses may occur due to e.g. gaseous transformation [16], binding to sediment [16, 17], trapping in interstitial spaces $[18]$ and uptake by primary producers $[16$, 19].

As an alternative to water column sampling, tissue nutrients of marine macroalgae have been suggested as a reliable indicator of bioavailable nutrients, in some cases superior to traditional water sampling (e.g. [12, 20, 21]). There are considerable amounts of data linking tissue nutrient status of algae to the nutrient history of the site (e.g. [22-24]). A recent study has shown that macroalgal tissue nutrient content could reflect long term changes in nutrient loading, where water column nutrients remained unchanged [21]. This might be explained by rapid macroalgal nutrient uptake that may significantly affect water column nutrient levels [25, 26]. In turn, this suggests that algal tissue nutrient content is not necessarily correlated to water column nutrient concentrations, but rather indicating nutrient loading and availability within the system. In addition to immediate nutrient consumption for growth, macroalgae are capable of nutrient storage and thereby incorporation over periods of time (e.g. $[27,28])$, thus being able to assimilate nutrient pulses [29].

Macroalgae with a high surface-area: volume ratio (SA:V ratio) (such as Ulva) tend to require more nutrients per unit of time and biomass in relation to those with a lower ratio, allowing a higher maximal uptake rate and production [30, 31]. Ulva spp. has also been shown to have a low nutrient storage capacity, compared to more persistent macroalgae 
[32]. Nutrient uptake and storage affects the algae's attributes as indicators for nutrient loading, as the response time (to changes in nutrient loading) depends on metabolic properties, where rapid nutrient turnover results in better reflection of current nutrient availability. However, the low storage capacity would also render Ulva an unsuitable indicator for historical nutrient loading at a studied site. Low storage capacity and rapid tissue nutrient turnover may pose a problem when sampling over time, as fluctuations between sampling occasions can be expected. Most studies on nutrient incorporation and turnover in Ulva tissues have been conducted in the lab (e.g. [14, 22, 23, 26, 33]), but very little experimental field-data exists.

The aim of this study is to evaluate the use of the macroalgal genus Ulva as an indicator for nutrient loading. To test the method, our study was designed to confirm the existence of two previously reported nutrient gradients, as well as to investigate the existence of a gradient in a relatively pristine area. Development of a new method for nutrient monitoring is especially important along the studied section of the East African coast, as existing nutrient data from the water column is scarce and new data is hard to obtain in many areas. The use of bioindicators could therefore be an important complement to water column sampling, but its use needs further evaluation in field studies.

\section{MATERIALS AND METHODOLOGY}

\section{Study Area and Survey Methods}

This study was conducted at three locations along the coast of East Africa. Each location was divided into a nutrient gradient from the nearby city or town, and represented by three sampling sites at increasing distance from the main nutrient source (city or town). The first location is situated in the vicinity of Dar es Salaam (Tanzania) (Fig. 1), and was sampled during January 2005. The second location is situated in the southernmost part of Kenya, outside Shimoni town. The third location is situated in the vicinity of Mombasa (Kenya) (Fig. 1). Both Shimoni and Mombasa were sampled during April 2007. Sampling during both years fall within the dry season and hence experience relatively low amounts of rainfall and subsequent runoff, minimizing influence from local sources. The sites within each location are referred to as A-C, with increasing distance from source (Fig. 1). The Dar es Salaam sites were Oyster bay (A), Mbudya (B) and Kunduchi (C). The Shimoni sites were Wasini island (A), Mpunguti wa Chini (B) and Mpunguti wa Juu (C). The Mombasa sites included Mombasa creek (A), Nyali (B) and Ras Iwatine (C). Tissue nutrients from the sampled sites were compared within each location in order to reflect assumed nutrient gradients. The prevailing currents in the study region flow from south to north throughout the year [34], thus our studied sites are mainly affected by nutrient sources to the south.

\section{Nutrient Gradients}

Many coastal waters in the region are in relatively pristine condition (with respect to nutrient loading), except for areas in the vicinity of major cities. For example, both Dar es Salaam and Mombasa are considered major sources of pollution and nutrient loading (e.g. [35-37]). The high loading from Dar es Salaam has previously been confirmed by

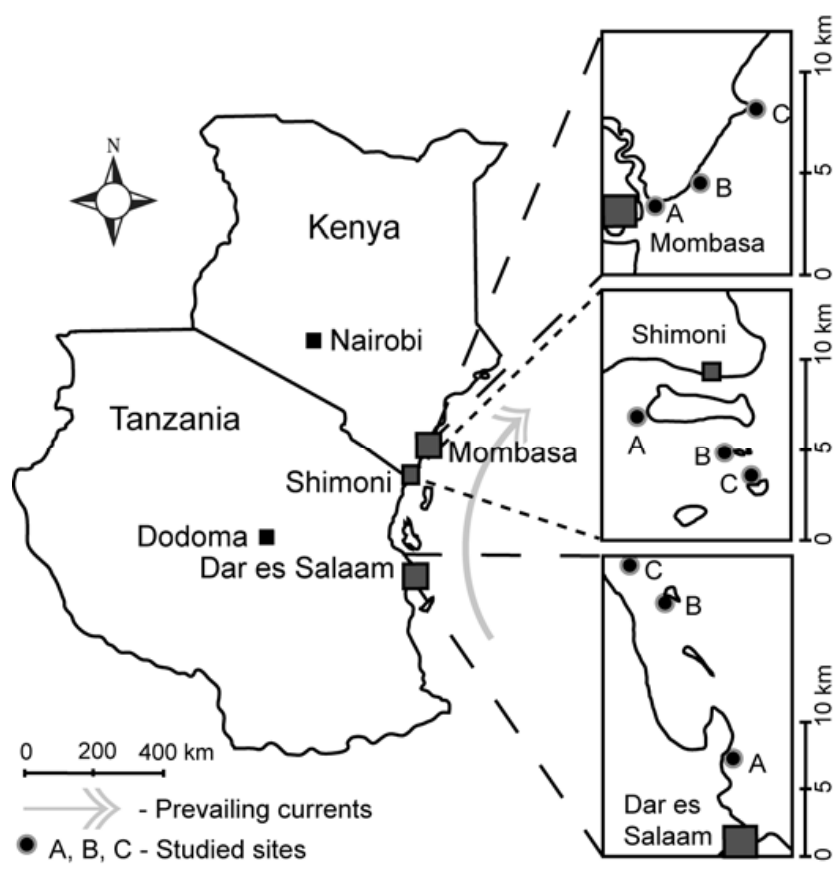

Fig. (1). Map of the region, study locations and sites. The study sites at each location are labeled A-C in accordance with proximity to the nutrient source.

Lugendo and colleagues (1999), who reported significantly higher $\mathrm{NH}_{4}$ levels at site $\mathrm{A}(\sim 9 \mu \mathrm{M})$ than at site $\mathrm{C}(\sim 2 \mu \mathrm{M})$. The $\mathrm{NO}_{3}$ and $\mathrm{PO}_{4}$ levels outside Daar es Salaam were $\sim 2.4$ and $\sim 1.5 \mu \mathrm{M}$, respectively [38]. The Mombasa area has been subjected to relatively high levels of nutrients for a long period of time [39, 40], and is considered eutrophicated [40]. This area has been reported to experience levels of $\mathrm{NO}_{\mathrm{x}}$ and $\mathrm{PO}_{4}$, ranging between $1-3 \mu \mathrm{M}$ and $\sim 0.3 \mu \mathrm{M}$ respectively [41]. According to Kleypas and colleagues [42], 90\% of coral reef areas worldwide have $\mathrm{NO}_{3}$ and $\mathrm{PO}_{4}$ levels below 0.6 and $0.2 \mu \mathrm{M}$ respectively, which is distinctly below the levels reported for the two cities in this study. Furthermore, it has been shown that nutrient levels in the vicinity of Mombasa are higher than at sites further to the north (e.g. [43]). Shimoni is a smaller town with only a few thousand people in the area. The gradient in this area is different as it originates from a smaller settlement and was sampled along a chain of islands, with increasing distance from the mainland. With its low anthropogenic influence, this area can be assumed relatively pristine, but there are no water nutrient data reported.

A large fraction of the waterborne nutrients in the study region originates from urban sewage [37]. However, these nutrients could not be separated from natural nutrient inputs (even though these are expected to be relatively low), therefore the measured tissue nutrient content reflects total nutrient availability, not exclusively anthropogenic loading.

\section{Species Description}

Tissue nutrient content of the genus Ulva (Chlorophyceae) was used to reflect the three nutrient gradients. The genus was chosen for its high uptake capacity [44], enabling it to respond faster and more clearly than many other macro- 


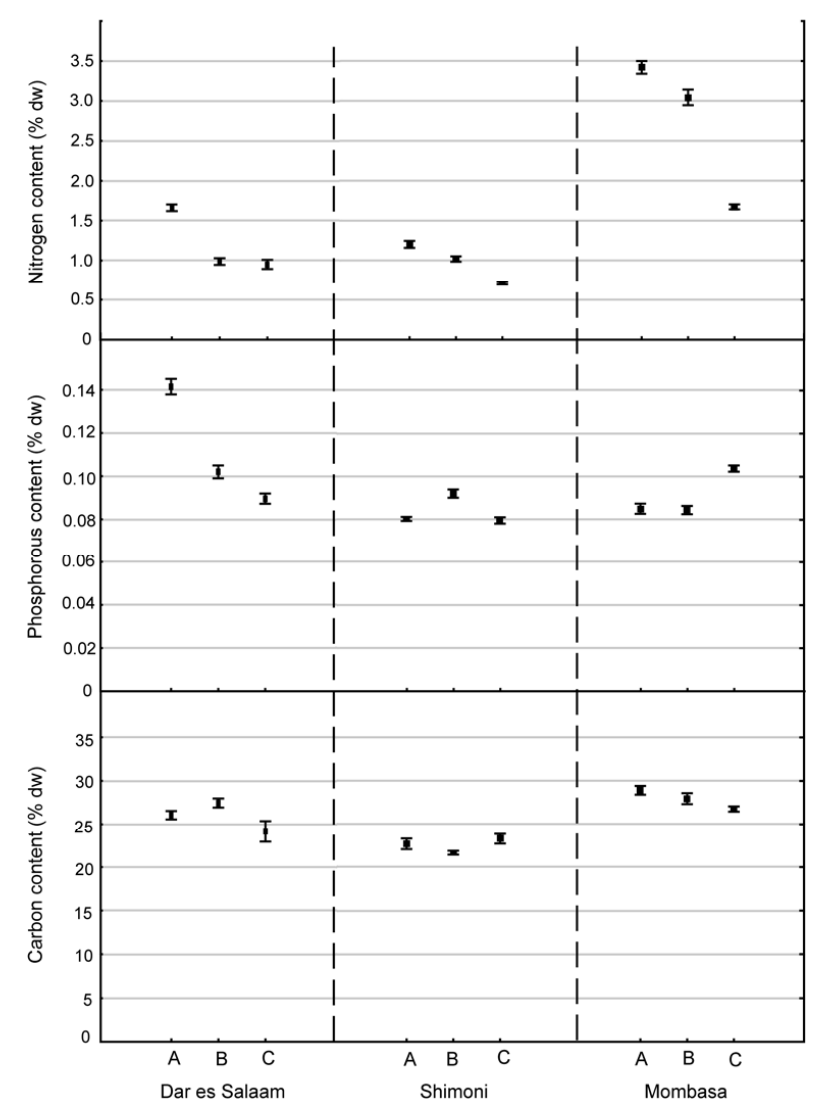

Fig. (2). Mean ( \pm SE) Ulva tissue nutrient content of N, P and C (\% of dw) from nutrient gradients outside Dar es Salaam, Shimoni and Mombasa $(n=10)$.

algal genera. Campbell [26] showed that Ulva, with a high internal $\mathrm{N}$ concentration, could support growth for about 6 days in a nutrient depleted medium, after which their internal nutrient storage was depleted. This indication of nutrient turnover suggests that Ulva tissue nutrient content can fluctuate significantly over shorter time periods. The three sites within each gradient were therefore sampled within 48 hours, in order to minimize temporal variation within the locations. Due to geographic variations in species occurrence, two species within the genera have represented different locations. Ulva pulchra (Jaasund) was used in the two southern locations, while Mombasa was represented by Ulva reticulata (Forsskål). Both species have similar morphology and $\mathrm{SA}: \mathrm{V}$ ratio, suggesting comparable nutrient uptakecapacity [45].

\section{Sampling and Analysis of Tissue Nutrient Content}

A total of ten individuals were collected from each site at each sampling occasion. All samples were collected in the subtidal at about $0.5-1 \mathrm{~m}$ depth (at spring low-tide). Tissue samples from the collected Ulva individuals were dried and analyzed for tissue content of nitrogen $(\mathrm{N})$, phosphorous (P) and carbon (C). In preparation for the analyses, the dried algae were ground into a fine powder and dried again at $60^{\circ} \mathrm{C}$ for $12 \mathrm{~h}$. Analyses were performed using a Shimadzu Total Organic Carbon Analyzer (model TOC-5000), giving the mass \% dry weight ( $\mathrm{dw}$ ) of $\mathrm{N}$ and $\mathrm{C}$ in tissues. $\mathrm{P}$ analyses were conducted by combustion of samples for $2 \mathrm{~h}$ at $500^{\circ} \mathrm{C}$ before digestion in persulfat solution $\left(50 \mathrm{~g}+30 \mathrm{ml} \mathrm{H}_{2} \mathrm{SO}_{4} \mathrm{l}^{-1}\right)$ for $1 \mathrm{~h}$ at $120^{\circ} \mathrm{C}$. Orthophosphate in the samples were then analyzed colorimetrically using a segmented flow system.

\section{Nutrient Fluctuation Over Time}

Fluctuations of tissue nutrient content in Ulva reticulata was investigated at site $\mathrm{C}$ in the Mombasa area (Fig. 1), during two periods in 2006 and 2007 (one month during each dry season). Sampling was conducted at varying intervals in order to detect short- and long-term variations. In 2006, sampling was conducted during Aug-Sept, at day 1, 3, 19 and 37. In 2007, the study period ranged from Feb-Mar, and was sampled at day 1, 7, and 33. Sampling was conducted during the dry seasons, as they are climatically stabile, with low wave action and precipitation [34]. A total of 10 individuals were collected at each sampling occasion.

\section{Nutrient Enrichment Experiment}

A nutrient enrichment experiment was conducted during Mar 2007 (at site C, Mombasa area) in order to investigate the response to a short-term nutrient pulse (48h). Increased nutrient loading was achieved by fastening meshbags, containing $10 \mathrm{~g}$ of Scotts NPK (Nitrogen: Phosphorous: Potassium) slow release fertilizer, right next to each fertilized algae. Both fertilized $(n=10)$ and control algae $(n=10)$ were randomly selected and sampled from the same site.

\section{STATISTICS}

ANOVAs were used to compare tissue nutrients between sites. ANOVA assumptions were tested using: Cochran's Ctest for homogeneity of variances, plot of residuals in order to see if data were normally distributed, and a regression between variances and means to make sure they were not correlated. When all ANOVA assumptions were fulfilled, Tukey's HSD-test was used. Whenever ANOVA assumptions were not fulfilled, nonparametric tests were used; i.e. Kruskal-Wallis ANOVA (KW) and Mann-Whitney U-test (MWU). All analyses were conducted using the software STATISTICA 7.1.

\section{RESULTS}

\section{Nutrient Gradients}

Sites in the Dar es Salaam area differed significantly between each other, regarding $\mathrm{N}$ (ANOVA $F_{2}=68.41$, $\mathrm{p}<0.001), \mathrm{P}\left(\right.$ ANOVA $\left.F_{2}=78.12, \mathrm{p}<0.001\right)$ and $\mathrm{C}(\mathrm{KW}$ $\mathrm{p}<0.05)$. Tissue from site $A$ had significantly higher nutrient content than the other two sites, for both $\mathrm{N}$ (HSD $\mathrm{p}<0.001)$ and $\mathrm{P}$ (HSD $\mathrm{p}<0.001$ ). Tissue from site $\mathrm{B}$ did not differ from site $\mathrm{C}$ regarding $\mathrm{N}$, but had significantly higher $\mathrm{P}$ content (HSD p <0.05) (Fig. 2). Tissue carbon content from site $B$ was significantly higher than at site $\mathrm{C}(\mathrm{MWU}$-test; $\mathrm{p}<0.05)$, while the other sites did not differ between each other (Fig. 2).

Significant differences were also found between sites in the Shimoni area, regarding $\mathrm{N}$ (ANOVA $F_{2}=72.76$, $\mathrm{p}<0.001), \mathrm{P}\left(\right.$ ANOVA $\left.F_{2}=20.66, \mathrm{p}<0.001\right)$ and $\mathrm{C}(\mathrm{KW}$ $\mathrm{p}<0.01)$. Tissue $\mathrm{N}$ levels were significantly higher in site $\mathrm{A}$ than in both site B (HSD p<0.01) and site C (HSD p<0.001). 
Table 1. Mean Weight \% N,P, C $( \pm$ SE) and C:N:P Ratios in Ulva Tissues at the Study Sites

\begin{tabular}{|c|c|c|c|c|}
\hline & $\begin{array}{c}\text { C Content } \\
(\%)\end{array}$ & $\begin{array}{c}\text { N Content } \\
(\%)\end{array}$ & $\begin{array}{c}\text { P Content } \\
(\%)\end{array}$ & $\begin{array}{l}\text { C:N:P } \\
\text { Ratio }\end{array}$ \\
\hline \multicolumn{5}{|c|}{ Dar es Salaam } \\
\hline A & $26.05(1.21)$ & $1.66(0.04)$ & $0.14(0.004)$ & $268: 12: 1$ \\
\hline $\mathrm{B}$ & $27.45(0.52)$ & $0.99(0.04)$ & $0.10(0.003)$ & 274:10:1 \\
\hline $\mathrm{C}$ & $24.14(0.49)$ & $0.95(0.06)$ & $0.09(0.002)$ & 186:11:1 \\
\hline \multicolumn{5}{|c|}{ Shimoni } \\
\hline A & $22.69(0.62)$ & $1.20(0.04)$ & $0.08(0.001)$ & $283: 15: 1$ \\
\hline B & $21.67(0.23)$ & $1.02(0.03)$ & $0.09(0.002)$ & $237: 11: 1$ \\
\hline $\mathrm{C}$ & $23.29(0.59)$ & $0.71(0.02)$ & $0.08(0.002)$ & 293:9:1 \\
\hline \multicolumn{5}{|c|}{ Mombasa } \\
\hline A & $28.92(0.51)$ & $3.42(0.08)$ & $0.09(0.002)$ & $342: 40: 1$ \\
\hline B & $27.97(0.66)$ & $3.04(0.10)$ & $0.08(0.002)$ & $332: 36: 1$ \\
\hline $\mathrm{C}$ & $26.76(0.30)$ & $1.67(0.03)$ & $0.10(0.001)$ & $259: 16: 1$ \\
\hline
\end{tabular}

In site $\mathrm{B}$, tissue $\mathrm{N}$ content was higher than in site $\mathrm{C}$ (HSD $\mathrm{p}<0.001$ ) (Fig. 2). Tissue $\mathrm{P}$ content was significantly higher in $\mathrm{B}$ than in both the other sites (HSD $\mathrm{p}<0.001$ ), which did not differ between each other (Fig. 2). Tissue carbon content from site $\mathrm{A}$ and $\mathrm{C}$ was significantly higher than from site $\mathrm{B}$ (MWU-test; $\mathrm{p}<0.01$ and MWU-test; $\mathrm{p}<0.05$, respectively), while $\mathrm{A}$ and $\mathrm{C}$ did not differ between each other (Fig. 2).

The same pattern was found outside Mombasa, where all sites differed significantly between each other, regarding $\mathrm{N}$ (ANOVA $F_{2}=218.95, \mathrm{p}<0.001$ ), $\mathrm{P}$ (ANOVA $F_{2}=30.32$, $\mathrm{p}<0.001)$ and $\mathrm{C}\left(\mathrm{ANOVA} F_{2}=4.48, \mathrm{p}<0.05\right)$. Tissue $\mathrm{N}$ was significantly higher in site A than in both site B (HSD $\mathrm{p}<0.05)$ and site $\mathrm{C}(\mathrm{HSD} \mathrm{p}<0.001)$. In turn, tissue from site $\mathrm{B}$ contained more $\mathrm{N}$ than tissue from site $\mathrm{C}$ (HSD $\mathrm{p}<0.001$ ) (Fig. 2). Tissue $\mathrm{P}$ content was significantly higher in site $\mathrm{C}$ than in both the other sites (HSD $\mathrm{p}<0.001$ ), which did not differ between each other (Fig. 2). Tissue from site A had significantly higher carbon content than tissue from site $\mathrm{C}$ (HSD $\mathrm{p}<0.05$ ), while there were no other significant differences between sites (Fig. 2).

$\mathrm{C}: \mathrm{N}: \mathrm{P}$ ratios in Ulva tissues varied between sites. The two sites close to Mombasa displayed the highest N:P ratios in the region (Table 1). N:P ratios did not vary between sites along the Dar es Salaam gradient. N:P ratios varied significantly within the Shimoni gradient $(\mathrm{KW} \mathrm{p}<0.001)$, where site A had a significantly higher $\mathrm{N}: \mathrm{P}$ ratio than both other sites (MWU $\mathrm{p}<0.001)$ and site $\mathrm{B}$ had a higher ratio than site C (MWU $\mathrm{p}<0.001)$. The Mombasa gradient followed the same pattern $(\mathrm{KW} \mathrm{p}<0.001)$, site A was significantly higher than both site B (MWU p<0.05) and C (MWU p<0.001).

\section{Nutrient Fluctuations Over Time}

Tissue $\mathrm{N}$ content fluctuated significantly during both 2006 (ANOVA $F_{3}=61.85, \mathrm{p}<0.001$ ) and 2007 (ANOVA $\left.F_{2}=64.46, \mathrm{p}<0.001\right)$, where each sampling occasion was significantly separated from the following (HSD p<0.001) (Fig.
3). Similar significant fluctuations were found for $\mathrm{P}$ during both 2006 (ANOVA $F_{3}=43.21, \mathrm{p}<0.001$ ) and 2007 (ANOVA $\left.F_{2}=11.68, \mathrm{p}<0.001\right)$. All sampling occasions were significantly separated from the following during both years (HSD $\mathrm{p}_{1-3} 2006<0.05$; all other $\mathrm{p}<0.001$ ) (Fig. 3). Tissue $\mathrm{C}$ content also fluctuated significantly during both 2006 (ANOVA $F_{3}=32.66, \mathrm{p}<0.001$ ) and 2007 (ANOVA $F_{2}=19.94$, p <0.001), where each sampling occasion was significantly separated from the following (HSD $\mathrm{p}_{1-7} 2007<0.01$; all other $\mathrm{p}<0.001$ ) (Fig. 3). Tissue nutrient content fluctuated with a maximum of $110 \%$ for $\mathrm{N}$ and $50 \%$ for $\mathrm{P}$ between sampling occasions (Fig. 3).

\section{Nutrient Enrichment Experiment}

Nutrient addition resulted in significantly higher tissue nutrient concentration after 2 days of exposure compared to controls, for both $\mathrm{N}$ (ANOVA $\left.F_{l}=17.68, \mathrm{p}<0.001\right)$ and $\mathrm{P}$ (ANOVA $F_{l}=5.40, \mathrm{p}<0.05$ ). However, tissue $\mathrm{C}$ content did not differ after treatment (ANOVA $F_{l}=0.47, \mathrm{p}=0.50$ ) (Fig. 4).

\section{DISCUSSION}

The present study shows that the genus Ulva has potential as indicator for relative nutrient loading, and for detecting nutrient gradients of the growth-limiting nutrient $(\mathrm{N})$. Such an indicator would be especially useful in regions where nutrient turnover in the water column is rapid, and water samples therefore may not be representative of the prevailing nutrient conditions.

Previous studies have suggested that macroalgal tissue often has higher $\mathrm{N}: \mathrm{P}$ ratios than found in the present study. For example, Duarte [46] calculated the mean N:P ratio (\% of dry weight) to $49: 1$, for 46 macroalgal species. Other studies (e.g. [47, 48]) have also presented ratios that exceed the suggested ratio of 30:1 [49], after which $P$ generally becomes limiting for tropical macroalgae. Although these reference values are from other regions (both tropical and tem- 


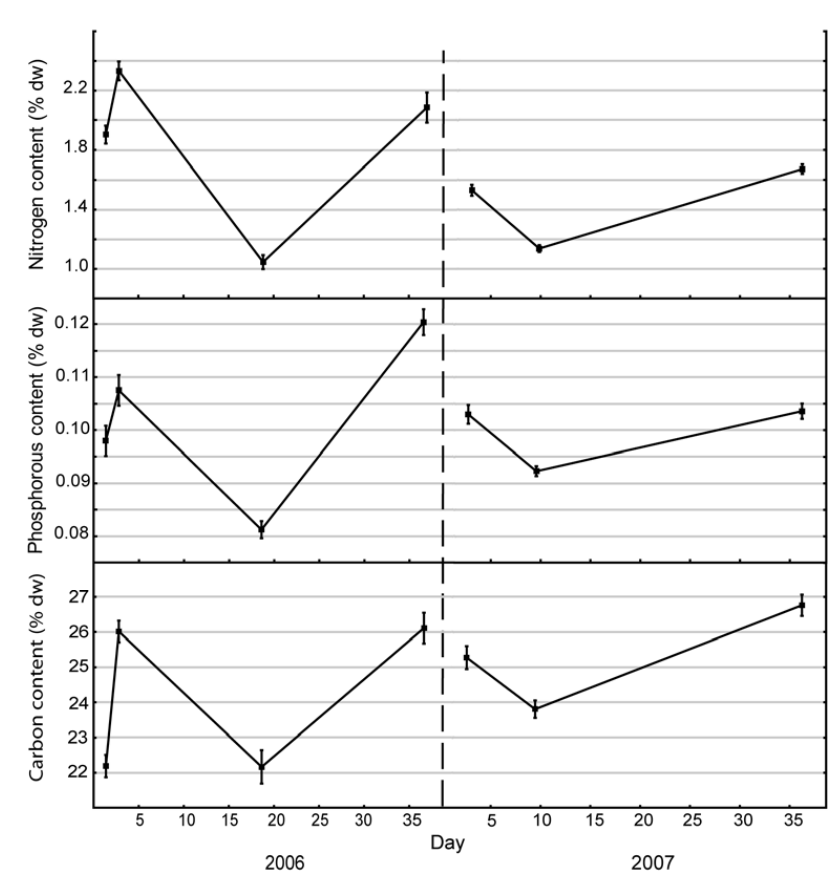

Fig. (3). Fluctuations in mean $( \pm \mathrm{SE})$ Ulva tissue content of $\mathrm{N}, \mathrm{P}$ and C (\% dw), during Aug-Sept 2006 and Feb-Mar 2007. Note - the $\mathrm{Y}$-axis does not start from 0 , in order to better illustrate the similarity in fluctuation-patterns $(\mathrm{n}=10)$.

perate), it is unlikely that the large differences (magnitude of factor 3) from values in the present study are due to geographical variations alone. Compared to reference values, most ratios and tissue $\mathrm{N}$ concentrations presented in this study (N:P ratios between 9:1 and 16:1) would be considered low, suggesting $\mathrm{N}$ limitation at all sites, except for the two closest to Mombasa. This contradicts the common assumption of $\mathrm{P}$ limitation in tropical areas (e.g. [48, 50-53]), especially as the present study showed the same pattern in both eutrophicated and pristine areas. N:P ratios tended to decrease along the gradients, which was mainly attributed to declines in $\mathrm{N}$ content, rather than increases in $\mathrm{P}$ content (Table 1). Furthermore, the critical tissue $\mathrm{N}$ concentration for unlimited growth is reported to be $2.2 \%$ for Ulva lactuca (Linnaeus) [44], and has previously been used to represent the genera [54]. Equivalent concentrations for $\mathrm{P}$ have been reported to be about $0.2 \%[54,55]$. Both $\mathrm{N}$ and $\mathrm{P}$ levels in this study are below critical tissue concentrations for optimal growth (Table 1), and some even approach the minimal limits after which growth have been reported to cease [54, 55]. The only exception is $\mathrm{N}$ levels in the Mombasa gradient, where sites $\mathrm{A}$ and $\mathrm{B}$ are well above critical concentration, while site $C$ is within the proposed critical range [55]. These low nutrient concentrations for both $\mathrm{N}$ and $\mathrm{P}$ are below what is needed for optimal growth, but the low N:P ratios indicate that $\mathrm{N}$ is the more limiting nutrient. Villares and Carrballeira [33] showed that Ulva rigida ceases to grow when tissue $\mathrm{N}$ concentrations are just below $\sim 1 \%$, while $\mathrm{P}$ can still support growth at levels as low as $\sim 0.03 \%$. In the present study, $\mathrm{N}$ levels at the low nutrient sites ranges around this threshold value $(1 \%)$, while the lowest $\mathrm{P}$ levels are more than double the proposed threshold $(0.03 \%)$. This further supports our assumption of $\mathrm{N}$ limitation. The nutrient fluctuation study showed that all three elements followed the same pattern (Fig. 3), while the enhancement experiment resulted in increased $\mathrm{N}$ and $\mathrm{P}$ without addition of $\mathrm{C}$ (Fig. 4). Macroalgal nutrient incorporation was therefore not found to be $\mathrm{C}$ limited in this study.

The lack of variation in tissue $\mathrm{P}$ levels could be explained by a rapid turnover and limited capacity for storage of excess $\mathrm{P}$ in Ulva tissue [56]. In an area where $\mathrm{P}$ supply is sufficient and $\mathrm{N}$ is limiting, $\mathrm{P}$ uptake could thus be assumed to reflect the requirements for growth and not luxury storage of tissue nutrients. This would explain why $\mathrm{P}$ did not follow the expected gradients in the same way as $\mathrm{N}$, in the present study. Further indications of nutrient limitation can be found in the similarity of tissue $\mathrm{N}$ and $\mathrm{P}$ variation over time, suggesting regulation by one of the nutrients (Fig. 3). Such variations could be the result of nutrient pulses, but could also be due to internal processes (e.g. [32]) or external prerequisites (e.g. tides and currents). However, regardless of the cause of the observed variance, it is important to recognize its existence, magnitude and how fast significant changes can occur, in order to design a suitable sampling strategy. If tissue nutrient levels are assumed to primarily reflect changes in nutrient availability, the study suggests that the amount of available nutrients in the region varies significantly, both between and within seasons (Fig. 3). The significant tissue nutrient variation over time also shows that Ulva is capable of nutrient assimilation and utilization, over relatively short time periods (Fig. 3). The observed nutrient uptake ability was also shown in the nutrient enhancement experiment, where a significant increase of tissue $\mathrm{N}$ and $\mathrm{P}$ could be detected even
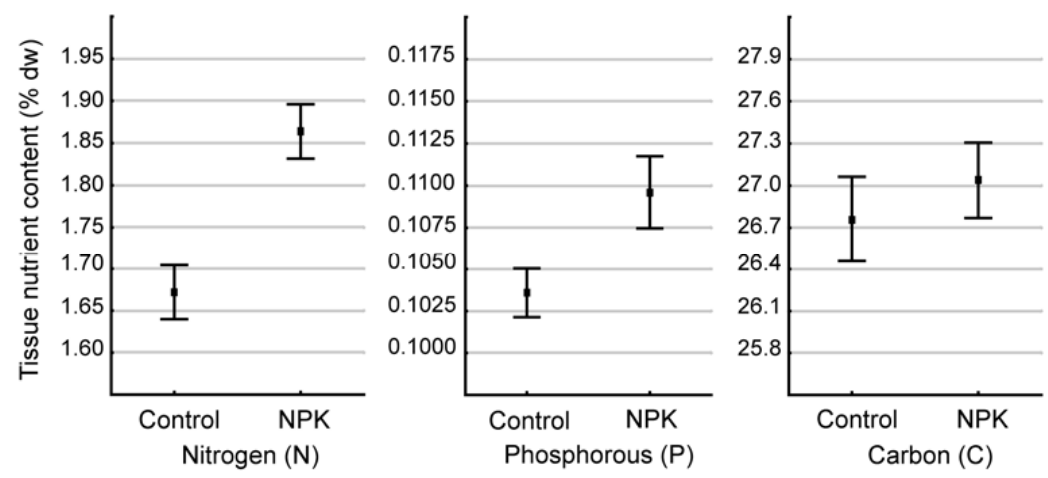

Fig. (4). Mean $( \pm \mathrm{SE})$ content of $\mathrm{N}, \mathrm{P}$ and $\mathrm{C}(\% \mathrm{dw})$ after $48 \mathrm{~h}$ in control group tissue (without nutrient additions) and fertilized tissue (with added NPK-fertilizer) $(\mathrm{n}=10)$. 
after 48h. Despite these fluctuations, macroalgal tissue nutrient concentrations should be stable, relative to more rapid water column nutrient fluctuations, as the algae integrate nutrients over time (e.g. $[27,28]$ ) and thereby dampen shortterm fluctuations. Such rapid nutrient uptake can be useful in detecting nutrient pulses and current nutrient availability, but may also complicate comparisons between samples collected during different periods. The high tissue nutrient turnover in the genus Ulva provides a strong connection to water column nutrient availability. However, its lack of long term nutrient storage makes it important to recognize that a single sampling occasion may be misleading when trying to reflect prevailing nutrient conditions in an area over longer time periods. If used correctly this method may be a useful tool in future monitoring of nutrients in East African waters.

\section{CONCLUSION}

Ulva tissue $\mathrm{N}$ concentrations could be used to reflect previously established gradients of nutrient loading outside two major cities. The technique was also able to detect a nutrient gradient emitting from a smaller settlement in a relatively pristine area. Thus, the study shows that macroalgal tissue nutrient content is a useful indicator of relative availability of growth-limiting nutrients in tropical waters. However, due to rapid nutrient turnover, sampling comparing nutrient levels between sites needs to be conducted within as short a time period as possible. The study shows that $\mathrm{N}$ is most likely to be the limiting nutrient in the study region, and we could therefore not find gradients regarding tissue $\mathrm{P}$ content. Thus, we could not evaluate Ulva's suitability as a bioindicator for prevailing $\mathrm{P}$ loading. Finally, we believe that the method described in this study has potential as a complement to regular water nutrient sampling.

\section{ACKNOWLEDGEMENTS}

We thank SIDA (Swedish International Development cooperation Agency) for funding the project. We are very grateful to Professor Nils Kautsky (Department of Systems Ecology, Stockholm University) and Dr. Tim McClanahan (Coral Reef Conservation Project, Mombasa) for valuable guidance and practical support. We are also grateful to Associate Professor Max Troell (Beijer Institute of Ecological Economics, Royal Swedish Academy of Science), Professor Lena Kautsky (Department of Botany, Stockholm University) and Professor Yunus Mgaya (Faculty of Aquatic Sciences and Technology, University of Dar es Salaam) for their valuable support and input to the study.

\section{LIST OF ABBREVIATIONS}

$\begin{array}{lll}\mathrm{SA}: \mathrm{V} \text { ratio } & = & \text { Surface area to volume ratio } \\ \mathrm{Dw} & = & \text { Dry weight }\end{array}$

\section{REFERENCES}

[1] McCook LJ. Macroalgae, nutrients and phase shifts on coral reefs: scientific issues and management consequences for the Great Barrier Reef. Coral Reefs 1999; 18(4): 357-67.

[2] Valiela I, McClelland J, Hauxwell J, Behr PJ, Hersh D, Foreman K. Macroalgal blooms in shallow estuaries: controls and ecophysiological and ecosystem consequences. Limnol Oceanogr 1997; 42(5): 1105-18.
Dahlgren S, Kautsky L. Can different vegetative states in shallow coastal bays of the Baltic Sea be linked to internal nutrient levels and external nutrient load? Hydrobiologia 2004; 514(1): 249-58.

Webster IT, Harris GP. Anthropogenic impacts on the ecosystems of coastal lagoons: modelling fundamental biogeochemical processes and management implications. Mar Freshwater Res 2004; 55(1): 67-78

Pearson TH, Rosenberg R. Macrobenthic succession in relation to organic enrichment and pollution of the marine environment. Oceanogr Mar Biol: Ann Rev 1978; 16: 229-311.

Sheffer M, Hosper SH, Meijer M-L, Moss B, Jeppesen E. Alternative equilibria in shallow lakes. Trends Ecol Evol 1993; 8: 275-9.

Troell M, Phil L, Rönnbäck P, Wennhage H, Söderquist T, Kautsky N. Regime shifts and ecosystem services in Swedish coastal soft bottom habitats: when resilience is undesirable. Ecol Soc 2005; 10(1): 30 .

Lapointe BE. Nutrient thresholds for eutrophication and macroalgal blooms on coral reefs in Jamaica and southeast Florida. Limnol Oceanogr 1997; 42: 1119-31.

Fong P, Zedler JB, Donohoe RM. Nitrogen vs. phosphorus limitation of algal biomass in shallow coastal lagoons. Limnol Oceanogr 1993; 38(5): 906-23.

Bilger RW, Atkinson MJ. Effects of nutrient loading on masstransfer rates to a coral-reef community. Limnol Oceanogr 1995; 40(2): 279-89.

Fong P, Donohoe RM, Zedler JB. Competition with macroalgae and benthic cyanobacterial mats limits phytoplankton abundance in experimental microcosms. Mar Ecol Prog Ser 1993; 100: 97-102.

Fong P, Kamer K, Boyer KE, Boyle KA. Nutrient content of macroalgae with differing morphologies may indicate sources of nutrients for tropical marine systems. Mar Ecol Prog Ser 2001; 220: 137-52.

Fong P, Zedler JB. Temperature and light effects on the seasonal succession of algal communities in shallow coastal lagoons. J Exp Mar Biol Ecol 1993; 171(2): 259-72.

Tyler AC, McGlathery KJ, Macko SA. Uptake of urea and amino acids by the macroalgae (Ulva lactuca) (Chlorophyta) and (Gracilaria vermiculophylla) (Rhodophyta). Mar Ecol Prog Ser 2005; 294: 161-72.

Lapointe BE, Oconell JD, Garret GS. Nutrient couplings between on-site sewage disposal systems, groundwaters, and near surface waters in the Florida Keys. Biogeochemistry 1990; 10: 289-307.

Smith SV. Phosphorus versus nitrogen limitation in the marineenvironment. Limnol Oceanogr 1984; 29(6): 1149-60.

Downing JA. Marine nitrogen: Phosphorus stoichiometry and the global N:P cycle. Biogeochemistry 1997; 37: 237-52.

Uthicke S, Klumpp DW. Microphytobenthos community production at a near-shore coral reef: seasonal variation and response to ammonium recycled by holothurians. Mar Ecol Prog Ser 1998; 169: 1-11.

Fong P, Zedler JB. Sources, sinks, and fluxes of nutrients $(\mathrm{N}+\mathrm{P})$ in a small highly modified urban estuary in southern California. Urban Ecosyst 2000; 4: 125-44.

Wheeler PA, Björnsäter BR. Seasonal fluctuations in tissue nitrogen, phosphorus, and N:P for five macroalgal species common on the pacific north west coast. J Phycol 1992; 28: 1-6.

Lourenço SO, Barbarino E, Nascimento A, Freitas JNP, Diniz GS. Tissue nitrogen and phosphorus in seaweeds in a tropical eutrophic environment: What a long-term study tells us. J Appl Phycol 2006; 18: 389-98.

Wheeler PA, North WN. Effects of nitrogen supply on nitrogen content and growth rate of juvenile Macrocystis pyrifera (Phaeophyta) sporophytes. J Phycol 1980; 16: 577-82.

Björnsäter BR, Wheeler PA. Effect of nitrogen and phosphorus supply on growth and tissue composition of Ulva fenestrate and Enteromorpha intestialis (Ulvales, Chlorophyta). J Phycol 1990; 26: 603-11.

Fong P, Boyer KE, Kamer K, Boyle KA. Influence of initial tissue nutrient status of tropical marine algae on response to nitrogen and phosphorus additions. Mar Ecol Prog Ser 2003; 262: 111-23.

Herbert RA. Nitrogen cycling in coastal marine ecosystems. FEMS Microbiol Rev1999; 23(5): 563-90.

Campbell S. Ammonium requirements of fast-growing ephemeral macroalgae in a nutrient-enriched marine embayment (Port Phillip Bay, Australia). Mar Ecol Prog Ser 2001; 209: 99-107. 
[27] Horrocks JL, Stewart GR, Dennison WC. Tissue nutrient content of Gracilaria spp. (Rhodophyta) and water quality along an estuarine gradient. Mar Freshwater Res 1995; 46: 975-83.

[28] Viaroli P, Bartoli M, Azzoni R, et al. Nutrient and iron limitation to Ulva blooms in a eutrophic coastal lagoon (Sacca di Goro, Italy). Hydrobiologia 2005; 550: 57-71.

[29] Costanzo SD, O'Donohue MJ, Dennison WC. (Rhodophyta) as a biological indicator of pulsed nutrients in oligotrophic waters. J Phycol 2000; 36: 680-5

[30] Wallentinus I. Comparisons of nutrient uptake rates for Baltic macroalgae with different thallus morphologies. Mar Biol 1984; 80: 215-25.

[31] Karez R, Engelbert S, Kraufvelin P, Pedersen MF, Sommer U. Biomass response and changes in composition of ephemeral macroalgal assemblages along an experimental gradient of nutrient enrichment. Aquat Bot 2004; 78(2): 103-17.

[32] Pedersen MF, Borum J. Nutrient control of algal growth in estuarine waters. Nutrient limitation and the importance of nitrogen requirements and nitrogen storage among phytoplankton and species of macroalgae. Mar Ecol Prog Ser 1996; 142: 261-72.

[33] Villares R, Carballeira A. Nutrient limitation in Macroalgae (Ulva and Enteromorpha) from the Rias Baixas (NW Spain). Mar Ecol 2004; 25(3): 225-43.

[34] McClanahan TR. Seasonality in East Africa's coastal waters. Mar Ecol Prog Ser 1988; 44: 191-9.

[35] Lusugga KJM. Dar es Salaam, Tanzania. In: Onibokun AG, Ed. Managing the Monster: Urban Waste and Governance in Africa. IDRC, Canada 1999.

[36] Ngusaru AS, Ed. The present state of knowledge of marine science in Tanzania, Synthesis report. Tanzania Coastal Management Partnership. Working Document 5047, 2000; p. 182.

[37] Obura DO. Kenya. Mar Poll Bull 2001; 42(12): 1264-78.

[38] Lugendo BR, Mgaya YD, Semsi AK. The seagrass and associated macroalgae at selected beaches along Dar es Salaam coast. 359373. In: Richmond MD, Francis J, Eds. Marine science development in Tanzania and eastern Africa. Proceeding of the $20^{\text {th }}$ anniversary conference on advances in marine science in Tanzania; 28 June - 1 July 1999, Zanzibar, Tanzania. IMS/WIOMSA 2001; p. 569.

[39] Kazungu JM, Dehairs F, Goeyens L. Nutrients distribution patterns in Tudor estuary (Mombasa, Kenya) during rainy season. Kenya $\mathbf{J}$ Sci Ser 1989; 10: 47-61.

[40] Osore MKW, Fiers F, Daro MH. Copepod composition, abundance and diversity in Makupa Creek, Mombasa, Kenya. W Indian Ocean J Mar Sci 2003; 2(1): 65-73.

[41] Osore MKW, Mwangi SN, Dzeha T, Kilonzo M, Daro MH. Plankton, nutrients and water quality: a comparative assessment of the mombasa marine protected area and mtwapa creek, Kenya. In: KMFRI GaK, Ed. Report on Status of Marine Pollution in Mom- basa Marine Park and Reserve and Mtwapa Creek, Kenya. 1999: p. 88.

[42] Kleypas JA, McManus JW, Menez LAB. Environmental limits to coral reef development: Where do we draw the line? Am Zool 1999; 39(1): 146-59.

[43] Uku J, Björk M. The distribution of epiphytic algae on three Kenyan seagrass species. S Afr J Bot 2001; 67: 475-82.

[44] Pedersen MF, Borum J. Nutrient control of estuarine macroalgae: growth strategy and the balance between nitrogen requirements and uptake. Mar Ecol Prog Ser 1997; 161: 155-63.

[45] Rosenberg GJR. Uptake of inorganic nitrogen and seaweed surface area:volume ratios. Aquat Bot 1984; 19: 65-72.

[46] Duarte CM. Nutrient concentration of aquatic plants - patterns across species. Limnol Oceanogr 1992; 37(4): 882-9.

[47] Atkinson MJ, Smith SV. C:N:P Ratios of benthic marine plants Limnol Oceanogr 1983; 28(3): 568-74.

[48] Lapointe BE, Littler MM, Littler DS. Nutrient availability to marine macroalgae in siliciclastic versus carbonate-rich coastal waters. Estuaries 1992; 15(1): 75-82.

[49] Larned ST. Nitrogen- versus phosphorus-limited growth and sources of nutrients for coral reef macroalgae. Mar Biol 1998; 132(3): 409-21.

[50] Lapointe BE. Strategies for pulsed nutrient supply to Gracilaria cultures in the Florida Keys: interactions between concentration and frequency of nutrient pulses. J Exp Mar Biol Ecol 1985; 93: 211-22.

[51] Lapointe BE. Phosphorus- and nitrogen-limited photosynthesis and growth of Gracilaria tikvahiae (Rhodophyceae) in the Florida Keys: an experimental field study. Mar Biol 1987; 93(4): 561-8.

[52] Littler MM, Littler DS, Lapointe BE. A comparison of nutrientand light-limited photosynthesis in psammophytic versus epilithic forms of Halimeda (Caulerpales, Halimedaceae) from the Bahamas. Coral Reefs 1988; 6(3): 219-25.

[53] Littler MM, Littler DS. Productivity and nutrient relationship in psammophytic versus epilithic forms of bryopsidales (Chlorophyta) - comparisons based on a short-term physiological assay. Hydrobiologia 1990; 204: 49-55

[54] Hernandez I, Fernandez-Engo MA, Perez-Llorens JL, Vergara JJ. Integrated outdoor culture of two estuarine macroalgae as biofilters for dissolved nutrients from Sparus aurata. J Appl Phycol 2005; 17: 557-67.

[55] Lyngby JE, Mortensen S, Ahrensberg N. Bioassessment techniques for monitoring of eutrophication and nutrient limitation in coastal ecosystems. Mar Poll Bull 1999; 39(1-12): 212-23.

[56] Runcie JW, Ritchie RJ, Larkum AWD. Uptake kinetics and assimilation of phosphorus by Catenella nipae and Ulva lactuca can be used to indicate ambient phosphate availability. J Appl Phycol 2004; 16(3): 181-94. 